\title{
LINGUISTIC EXPERIENCE AND LINGUISTIC HABIT
}

Yao Shen

University of Michigan and University of Hawaii

Time and again teachers of foreign languages are reminded of the importance of being aware of the difference between languages, for differences constitute learning problems. And different native languages can constitute different learning problems in learning the same foreign language. Some attention has also been given to the all-too-often neglected importance of seeking possible differences within "similarities," for "similarities" have been found to be "differences" and therefore they too constitute problems.

This article attempts to show further some of the intricate relationships between "similarities" and "differences" among languages. Examples used here are the voiceless and voiced bilabial, alveolar (dental), and velar stops in final position. The foreign language is English. The native languages are Tagalog, Javanese, Thai, Mandarin, and Japanese.

We shall now examine the learning problems involved when native speakers of these five languages produce the six stops in final position in English, with special attention to the voiced velar stop $/ g / .1$

There are pairs of words in English that are semantically and linguistically different. The minimal phonological difference is voicing. As far as the six stops in English are concerned, this minimal difference can occur initially, intervocalically, and finally (though these are not of course the only possibilities). For example:

$\begin{array}{lllllll}\text { /p/ } & \text { /pil/ } & \text { pill } & \text { /ræpid/ } & \text { rapid } & \text { /map/ } & \text { mop } \\ \text { /b/ } & \text { /bil/ } & \text { bill } & \text { /ræbid/ } & \text { rabid } & \text { /mab/ } & \text { mob } \\ & & & \text { /lætər/ } & \text { latter } & / \text { nat/ } & \text { not } \\ \text { /t/ } & \text { /til/ } & \text { till } & \text { /lædər/ } & \text { ladder } & / \text { nad/ } & \text { nod } \\ \text { /d/ } & \text { /dil/ } & \text { dill } & \text { / } & & & \\ & & & & \text { echo } & \text { /nak/ } & \text { knock } \\ \text { /k/ } & \text { /kil/ } & \text { kill } & \text { /ekow/ } & \text { ego } & \text { /nag/ } & \text { nog }\end{array}$


There are other pairs of words in English that are also semantically and linguistically different. The minimal phonological difference is the presence or absence of a vowel in each pair. The purpose of listing these will become clear when we consider the pronunciation of English final stops by speakers of Mandarin and Japanese.

Example 1.

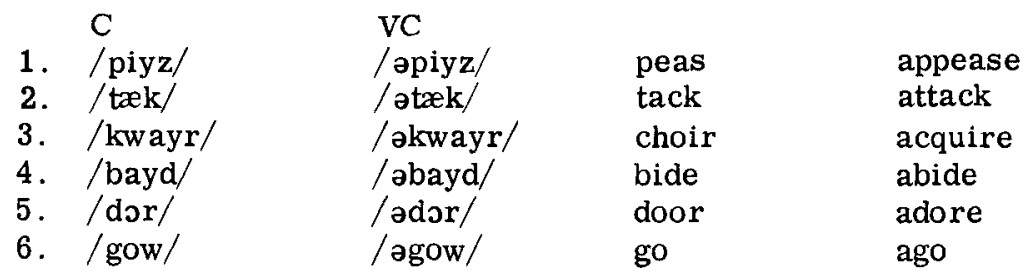

Example 2.

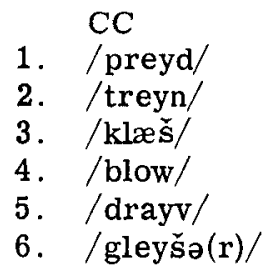

CVC

/pəreyd/

prayed

parade

/toreyn/

train

/kəlæšs/

clash

/bolow/

blow

/derayv/

drive

/gəleyša/

glacier

terrain

calash

below

derive

Galacia

Example 3 .

$\begin{array}{lllll} & \text { CC } & \text { CVC } & & \\ \text { 1. } & \text { læps/ } & \text { /læpəs/ } & \text { laps } & \text { lapis } \\ \text { 2. } \text { /fiyts/ } & \text { /fiytəs/ } & \text { feats } & \text { fetus } \\ \text { 3. /bæks/ } & \text { /bækəs/ } & \text { backs } & \text { Bacchus } \\ \text { 4. /kyuwb/ } & \text { /kyuwbəz/ } & \text { cubes } & \text { Cuba's } \\ \text { 5. /rowdz/ } & \text { /rowdəz/ } & \text { roads } & \text { Rhoda's } \\ \text { 6. /sagz/ } & \text { /sagəz/ } & \text { sogs } & \text { sagas }\end{array}$

Example 4.

$\mathrm{C}$

1. /stuwp/

2. /deyt/

3. /spayk/

4. /tuwb/

5. /sowd/

6. /veyg/

\section{CV}

/stuwpo/

/deyta/

/spayka/

/tuwba/

/sowdə/

/veyga/ stoop

date

spike

tube

sewed

vague stupa

data

spica

tuba

soda

Vega 
Let us now study the occurrences of the bilabial, alveolar (dental), and velar stops in these six languages.

$$
/ \mathrm{p}^{\prime} / \mathrm{t}^{\prime} / \mathrm{k}^{\prime} / \mathrm{p} / / \mathrm{t} / / \mathrm{k} / / \mathrm{b} / / \mathrm{d} / \mathrm{g} /
$$

English

Tagalog

Javanese

Japanese

Mandarin ${ }^{2}$

Thai

$\begin{array}{cccccc}\mathbf{x} & \mathbf{x} & \mathbf{x} & \mathbf{x} & \mathbf{x} & \mathbf{x} \\ \mathbf{x} & \mathbf{x} & \mathbf{x} & \mathbf{x} & \mathbf{x} & \mathbf{x} \\ \mathbf{x} & \mathbf{x} & \mathbf{x} & \mathbf{x} & \mathbf{x} & \mathbf{x} \\ \mathbf{x} & \mathbf{x} & \mathbf{x} & \mathbf{x} & \mathbf{x} & \mathbf{x} \\ \mathbf{x} & \mathbf{x} & \mathbf{x} & \mathbf{x} & \mathbf{x} & \mathbf{x} \\ \mathbf{x} & \mathbf{x} & \mathbf{x} & \mathbf{x} & \mathbf{x} & \end{array}$

The occurrences of the stops in final position in these six languages are as follows. ${ }^{3}$

$$
/-\mathrm{p} / \quad /-\mathrm{t} / \quad /-\mathrm{k} / \quad /-\mathrm{b} / \quad /-\mathrm{d} / \quad /-\mathrm{g} /
$$

English

Tagalog

Javanese

Thai

Mandarin

Japanese

$\begin{array}{cccccc}\mathbf{x} & \mathbf{x} & \mathbf{x} & \mathbf{x} & \mathbf{x} & \mathbf{x} \\ \mathbf{x} & \mathbf{x} & \mathbf{x} & \mathbf{x} & \mathbf{x} & \mathbf{x} \\ \mathbf{x} & \mathbf{x} & \mathbf{x} & \mathbf{x} & \mathbf{x} & \mathbf{x} \\ \mathbf{x} & \mathbf{x} & \mathbf{x} & & & \end{array}$

\begin{tabular}{|c|c|c|c|c|c|}
\hline & $/-\mathrm{p} /$ & $/-\mathrm{t} /$ & $\mid-\mathbf{k} /$ & $\mid-b /$ & $\mid-d /$ \\
\hline English ${ }^{4}$ & $\begin{array}{c}{\left[p^{\prime-}\right.} \\
p^{-} \\
\left.p^{\prime}\right]\end{array}$ & $\begin{array}{c}{\left[t^{\prime}\right.} \\
t^{-} \\
\left.t^{\prime}\right]\end{array}$ & $\begin{array}{c}{\left[\mathbf{k}^{\prime-}\right.} \\
\mathbf{k}^{-} \\
\left.\mathbf{k}^{\urcorner}\right]\end{array}$ & {$\left[\begin{array}{l}b^{-} \\
b^{\top}\end{array}\right]$} & {$\left[\begin{array}{l}d^{-} \\
\left.d^{\top}\right]\end{array}\right.$} \\
\hline Tagalog & {$\left[p^{\top}\right]$} & {$\left[t^{1}\right]$} & {$\left[\mathrm{k}^{\top}\right]$} & {$\left[b^{7}\right]$} & {$\left[d^{\top}\right]$} \\
\hline Javanese & {$\left[\mathrm{p}^{\prime}\right]$} & {$\left[t^{\top}\right]$} & {$\left[k^{\top}\right]$} & & \\
\hline Thai & {$\left[\mathrm{p}^{1}\right]$} & {$\left[t^{\top}\right]$} & {$\left[\mathrm{k}^{7}\right]$} & & \\
\hline
\end{tabular}

The final stops are realized in the following allophones.

Stops in intervocalic position in the six languages are realized in the following way. (This mark - means "varying freely with.") 


\begin{tabular}{|c|c|c|c|c|c|}
\hline English 4 & $\begin{array}{l}/-p-/ \\
{\left[p^{\prime-}\right.} \\
p]\end{array}$ & $\begin{array}{c}/-\mathrm{t}-/ \\
{\left[\mathrm{t}^{\prime-}\right.} \\
\mathrm{t}^{-} \\
\mathrm{t}^{-} \\
\mathrm{d}^{-} \\
\check{\mathrm{r}}]\end{array}$ & $\begin{array}{l}/-\mathrm{k}-/ \\
{\left[\mathrm{k}^{\prime-}\right.} \\
\mathrm{k}]\end{array}$ & $\begin{array}{l}/-b-/ \\
{[b]}\end{array}$ & $\begin{array}{l}/-d-/ \\
{[d]}\end{array}$ \\
\hline Tagalog & {$[\mathrm{p}]$} & {$[\mathrm{t}]$} & {$[\mathrm{k}]$} & {$[\mathbf{b}]$} & [d] \\
\hline Javanese & {$[p]$} & {$[t]$} & {$[\mathrm{k}]$} & {$[\mathbf{b}]$} & [d] \\
\hline Thai & {$[\mathrm{p}]$} & {$[t]$} & {$[\mathrm{k}]$} & [b] & [d] \\
\hline Mandarin & [p'] & {$\left[\mathrm{t}^{\prime}\right]$} & {$\left[\mathbf{k}^{\prime}\right]$} & $\begin{array}{l}{[\mathrm{p}]} \\
{[\mathrm{b}]}\end{array}$ & $\begin{array}{l}{[\mathrm{t}]} \\
{[\mathrm{d}]}\end{array}$ \\
\hline Japanese & {$[\mathrm{p}]$} & {$[t]$} & {$[\mathrm{k}]$} & {$[\mathrm{b}]^{5}$} & [d] \\
\hline
\end{tabular}

We shall use three pairs of test words in English to see how native speakers of Tagalog, Javanese, Thai, Mandarin, and Japanese produce the six final stops in English:

$\begin{array}{llllll}/ \mathrm{p} / & / \mathrm{map} / & \operatorname{mop} & / \mathrm{b} / & / \mathrm{mab} / & \operatorname{mob} \\ / \mathrm{t} / & / \text { nat/ } & \text { not } & / \mathrm{d} / & / \mathrm{nad} / & \text { nod } \\ / \mathrm{k} / & / \text { nak/ } & \text { knock } & / \mathrm{g} / & / \mathrm{nag} / & \text { nog }\end{array}$

The production of the six words in English by native speakers of the five languages is as follows.

$\begin{array}{lccccc}\text { English } & \text { Tagalog } & \text { Javanese } & \text { Thai } & \text { Mandarin } & \text { Japanese } \\ \text { /map/ } & \text { /map/ } & \text { /map/ } & \text { /map/ } & \text { /mapə/ } & \text { /mapu/ } \\ \text { /mab/ } & \text { /mab/ } & \text { /map/ } & \text { /map/ } & \text { /maba/ } & \text { /mabu/ } \\ \text { /nat/ } & \text { /nat/ } & \text { /nat/ } & \text { /nat/ } & \text { /nato/ } & \text { /nato/ } \\ \text { /nad/ } & \text { /nad/ } & \text { /nat/ } & \text { /nat/ } & \text { /nadə/ } & \text { /nado/ } \\ \text { /nak/ } & \text { /nak/ } & \text { /nak/ } & \text { /nak/ } & \text { /naka/ } & \text { /naku/ } \\ \text { /nag/ } & \text { /nag/ } & \text { /nak/ } & \text { /nak/ } & \text { /naka/ } & \text { /nagu/ }\end{array}$

There is no learning problem for the Tagalog speaker in producing the six stops in English. Similar to English, the six stops occur in Tagalog, and in final position.

$\begin{array}{llll}\text { English } & \text { Tagalog } & \text { English } & \text { Tagalog } \\ /--\mathrm{p} / & /--\mathrm{p} / & /--\mathrm{b} / & /-\mathrm{b} / \\ /-\mathrm{t} / & /--\mathrm{t} / & /--\mathrm{d} / & /-\mathrm{d} / \\ /--\mathrm{k} / & /--\mathrm{k} / & /--\mathrm{g} / & /--\mathrm{g} /\end{array}$


In other words, the Tagalog speaker has the linguistic experience in producing the six stops as well as the linguistic habit of producing them in final position.

$$
\begin{array}{lll}
\text { English } & / \mathrm{p}, \mathrm{t}, \mathrm{k}, \mathrm{b}, \mathrm{d}, \mathrm{g} / & {[-\mathrm{p},-\mathrm{t},-\mathrm{k},-\mathrm{b},-\mathrm{d},-\mathrm{g}]} \\
\text { Tagalog } & \text { familiar } \mathrm{g} \text { experience } & \text { familiar } \mathrm{g} \text { habit }
\end{array}
$$

There is no learning problem for the Javanese and Thai speakers in producing the three voiceless stops. Similar to English, the three voiceless stops occur in both native languages, and in final position.

$\begin{array}{ccc}\text { English } & \text { Javanese } & \text { Thai } \\ /--\mathrm{p} / & /--\mathrm{p} / & /--\mathrm{p} / \\ /--\mathrm{t} / & /--\mathrm{t} / & /--\mathrm{t} / \\ /--\mathrm{k} / & /--\mathrm{k} / & /--\mathrm{k} /\end{array}$

Thus both speakers have the linguistic experience of producing the three voiceless stops and the linguistic habit of producing them in final position.

$\begin{array}{lll}\text { English } & / \mathrm{p}, \mathrm{t}, \mathrm{k} / & {[-\mathrm{p},-\mathrm{t},-\mathrm{k}]} \\ \text { Javanese } & \text { familiar } \mathrm{lg} \text { experience } & \text { familiar } \mathrm{lg} \text { habit } \\ \text { Thai } & \text { familiar lg experience } & \text { familiar } \mathrm{lg} \text { habit }\end{array}$

There are two major types of production problems involved:

First, the substitution of the voiceless stops for the voiced ones by Javanese and Thai speakers. In Javanese and Thai, only voiceless stops occur in final position.

Second, the addition of vowels to the final stops by Mandarin and Japanese speakers. In Mandarin and Japanese, stops do not occur in final position.

We shall take up the Javanese and Thai speakers first. If we look at the nature of the substitution made by the Javanese and Thai speakers, we see an obvious similarity between the two, that is, both speakers produce the voiceless set for the voiced ones in English.

$\begin{array}{ccc}\text { English } & \text { Javanese } & \text { Thai } \\ /--\mathrm{b} / & /--\mathrm{p} / & /--\mathrm{p} / \\ /-\mathrm{d} / & /--\mathrm{t} / & /-\mathrm{t} / \\ /-\mathrm{g} / & /--\mathrm{k} / & /--\mathrm{k} /\end{array}$


If we study the linguistic habit necessary for producing the three voiced stops in English, the similarity is not parallel any more.

In Javanese, the three voiceless stops and the three voiced stops are contrastive in initial and intervocalic positions. In final position, the voiced set does not occur. For example:

$/ \mathrm{p} /$ /polo/ nutmeg /opo/ what /salap/ put

/b/ /bolo/ army /obo/ demand

$/ \mathrm{t} /$ /tamu/ guest /wuto/ blind /salat/ pray

/d/ /damu/ blow /wudo/ naked

/k/ /kula/ I /laku/ in demand /babak/ of the

/g/ /gulo/ sugar /lagu/ melody

The contrast between the voiceless set and voiced one in initial and in intervocalic positions is within the Javanese speaker's linguistic experience. The new linguistic habit he needs to acquire is the voiced set in final position.

$\begin{array}{ll}\text { English } & \text { Javanese } \\ \text { /-p/ /map/ } & \text { /salap/ } \\ \text { /-t/ /nat/ } & \text { /salat/ } \\ \text { /-k/ /nak/ / } / \text { babak/ } \\ \text { /-b/ /mab/ } \\ \text { /-d/ /nad/ } \\ \text { /-g/ /nag/ }\end{array}$

In other words, he must acquire new linguistic habits to supplement familiar linguistic experiences.
English
$/ \mathrm{b}, \mathrm{d}, \mathrm{g} /$
Javanese
familiar $\lg$ experience
$[-b,-d,-g]$
new $\lg$ habit

In English, vowels that occur before voiced consonants are longer than those that occur before voiceless ones. Thus an additional habit which the Javanese speaker should acquire is to produce the vowels before the voiced stops longer than those before the voiceless stops. If he produces vowel length followed by voiceless stops, native speakers of English may react to the voiceless set preceded by the longer vowels as the voiced set. For example:

$$
[\mathrm{map}] \rightarrow / \mathrm{map} / \quad[\mathrm{nat}] \rightarrow / \text { nat } / \quad[\mathrm{nak}] \rightarrow / \text { nak } /
$$




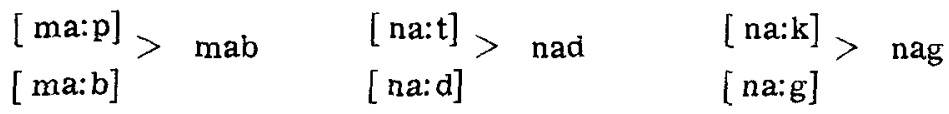

There is no vowel length in Javanese. If the Javenese speaker is allowed to substitute the voiceless stops for the voiced ones, then he must produce the predictably distributed difference in vowel length. Difference in vowel length to him, how ever, is not only a new linguistic habit but also a new linguistic experience.

$\begin{array}{ll}\text { English } & \text { vowel length } \\ \text { Javanese } & \text { new lg experience } \\ & \text { new lg habit }\end{array}$

If he is to produce the voiced stops as well, he must then also learn to acquire new linguistic habits with familiar linguistic experience.

$\begin{array}{lll}\text { English } & \text { vowel length } & / b, d, g[-b,-d,-g] / \\ \text { Javanese } & \text { new lg experience } & \text { familiar lg experience } \\ & \text { new lg habit } & \text { new lg habit }\end{array}$

Teaching the Thai speaker to produce the voiced bilabial and alveolar stops in final position is similar to teaching the same two stops to the Javanese speaker. For in both languages $/ b /$ and $/ d /$ occur, but in neither language do they occur in final position.

$\begin{array}{lll}\text { English } & / \mathrm{b}, \mathrm{d} / & {[-\mathrm{b},-\mathrm{d}]} \\ \text { Javanese } & \text { familiar lg experience } & \text { new } \mathrm{Ig} \text { habit } \\ \text { Thai } & \text { familiar } \text { lg experience } & \text { new ig habit }\end{array}$

But to teach the Thai speaker to produce the voiced velar stop in final position in English is different from teaching the same stop to the Javanese speaker in two ways.

First, there is a similarity in substitution-both the Javanese and the Thai tend to produce the voiceless stop for the voiced one.

\begin{tabular}{|c|c|c|c|c|}
\hline \multicolumn{3}{|c|}{$/ \mathbf{k} /$} & \multicolumn{2}{|r|}{$/ g /$} \\
\hline English & $/$ nak $/$ & {$\left[\mathrm{nak}^{\top}\right]$} & $\neq$ & $/ \mathrm{nag} /\left[\mathrm{nag}^{\top}\right]$ \\
\hline Javanese & & {$\left[\mathrm{nak}^{\top}\right]$} & & {$\left[\mathrm{nak}^{\top}\right]$} \\
\hline Thai & & {$\left[\operatorname{nak}^{7}\right]$} & & {$\left[\mathrm{nak}^{1}\right]^{6}$} \\
\hline
\end{tabular}


But in Javanese, there is:

$$
/ \mathrm{p} / \neq / \mathrm{b} / \quad / \mathrm{t} / \neq / \mathrm{d} / \mathrm{k} / \neq \mathrm{g} /
$$

In Thai, the contrast in voicing does not occur in any position with the velar articulation.

$$
/ \mathrm{p} / \neq / \mathrm{b} / \quad / \mathrm{t} / \neq / \mathrm{d} / \quad / \mathrm{k} /
$$

There is no $/ \mathrm{g} /$ at all. Thus for the Thai speaker, to produce the voiced velar stop in English involves not only a new linguistic habit but also a new linguistic experience.

English

Thai

$$
/ \mathrm{g} /
$$

new lg experience<smiles>[Li][Ba]</smiles>

new $\lg$ habit

Second, in Thai, vowel length is phonemic, and the Thai speaker has the linguistic experience in making the distribution.

English

vowel length

Thai

$$
\text { familiar } \lg \text { experience }
$$

But in speaking English, he must produce only the long vowels -a new linguistic habit-before all three voiced stops, [-g] being one of them.

$\begin{array}{lll}\text { English } & \text { vowel length } & / g[-g] / \\ \text { Thai } & \text { familiar lg experience } & \text { new lg experience } \\ & \text { new lg habit } & \text { new lg habit }\end{array}$

Between the Javanese speaker and the Thai speaker, the substitution of the voiceless stops for the voiced one is similar. But for each speaker, the linguistic experience and the linguistic habit concerned in producing the voiced set are not similar. Learning to produce the voiced velar stop in English, the Javanese speaker must acquire a new linguistic experience (short and long vowels) to form a new linguistic habit (long vowels only) followed by a familiar linguistic experience $(/ \mathrm{g} /)$ but a new Iinguistic habit $([-\mathrm{g}])$. On the other hand, the Thai speaker must select from a familiar linguistic experience (short and long vowels) to form a new linguistic habit (long vowels only) followed by a new linguistic experience $(\mathrm{g} /)$ which is also a new linguistic habit $([-\mathrm{g}])$. 


$\begin{array}{lll}\text { English } & \text { long vowel } & / \mathrm{g}[-\mathrm{g}] / \\ \text { Javanese } & \text { new } \mathrm{lg} \text { experience } & \text { familiar } \mathrm{lg} \text { experience } \\ & \text { new } \mathrm{lg} \text { habit } & \text { new } \mathrm{g} \text { habit } \\ \text { Thai } & \text { familiar } \mathrm{lg} \text { experience } & \text { new } \mathrm{lg} \text { experience } \\ & \text { new } \mathrm{lg} \text { habit } & \text { new } \mathrm{lg} \text { habit }\end{array}$

Let us now examine how the Mandarin and the Japanese speakers produce the six stops in final position in English.

$\begin{array}{lll}\text { English } & \text { Mandarin } & \text { Japanese } \\ \text { /map/ } & \text { /mapə/ } & \text { /mapu/ } \\ \text { /mab/ } & \text { /mabə/ } & \text { /mabu/ } \\ \text { /nat/ } & \text { /nato/ } & \text { /nato/ } \\ \text { /nad/ } & \text { /nadə/ } & \text { /nado/ } \\ \text { /nak/ } & \text { /nakə/ } & \text { /naku/ } \\ \text { /nag/ } & \text { /nago/ } & \text { /nagu/ }\end{array}$

There is a similarity in the production of the voiceless and the voiced sets-Mandarin and Japanese speakers produce all six stops.

$\begin{array}{lll}\text { English } & \text { Mandarin } & \text { Japanese } \\ / \mathrm{p} / & / \mathrm{p} / & / \mathrm{p} / \\ / \mathrm{b} / & / \mathrm{b} / & / \mathrm{b} / \\ / \mathrm{t} / & / \mathrm{t} / & / \mathrm{t} / \\ / \mathrm{d} / & / \mathrm{d} / & / \mathrm{d} / \\ / \mathrm{k} / & / \mathrm{k} / & / \mathrm{k} / \\ / \mathrm{g} / & / \mathrm{g} / & / \mathrm{g} /\end{array}$

There is also a similarity in the addition of a vowel to all the stops-English words that end in $\mathrm{C}$ now end in $\mathrm{CV}$.

$\begin{array}{ccc}\text { English } & \text { Mandarin } & \text { Japanese } \\ \mathrm{C} & \mathrm{CV} & \mathrm{CV} \\ /--\mathrm{p} / & /--\mathrm{p}-/ & /--\mathrm{p}-/ \\ /-\mathrm{b} / & /--\mathrm{b}-/ & /--\mathrm{b}-/ \\ /-\mathrm{t} / & /--\mathrm{t}-/ & /--\mathrm{t}-/ \\ /-\mathrm{d} / & /--\mathrm{d}-/ & /--\mathrm{d}-/ \\ /-\mathrm{k} / & /--\mathrm{k}-/ & /--\mathrm{k}-/ \\ /-\mathrm{g} / & /--\mathrm{g}-/ & /--\mathrm{g}-/\end{array}$


There is a difference in the vowels added. The Mandarin speaker consistently adds /a/ to all six stops. The Japanese speaker adds the high-back /u/ to the bilabial /p,b/ and the $\operatorname{velar} / \mathrm{k}, \mathrm{g} / \mathrm{stops}$, and the mid-back /o/ to the alveolar $/ \mathrm{t}, \mathrm{d} /$ stops.

\begin{tabular}{|c|c|c|}
\hline English & Mandarin & Japanese \\
\hline$/--p /$ & /--pə/ & $/--p u /$ \\
\hline & & \\
\hline $\mid \begin{array}{l}|--\mathrm{k}| \\
\mid--\mathrm{g} /\end{array}$ & & \\
\hline $\mid \begin{array}{l}\mid--t / \\
\mid--d /\end{array}$ & $\begin{array}{l}\mid--\mathrm{t} \partial / \\
|--\mathrm{d} \partial|\end{array}$ & $\begin{array}{l}/=- \text { to } / \\
/-- \text { do }\end{array}$ \\
\hline
\end{tabular}

There is a contrast in English between words that end with a stop and words with the same sound sequence followed by $/ \partial /$. For example:
1. /pip/
/pipo/
pip Pippa
2. /Ciyt/
/ Ciyta/
3. /powk/
/powkə/
4. /tuwb/
/tuwbə/
cheat cheetah
5. / kowd/
/kowde/
poke polka
6. /towg/
/towga/
tube tuba
code coda
togue toga

There is also a contrast in English between words that end with a stop and words with the same sound sequence followed by a vowel: high-back after the bilabial and velar, and mid-back after the alveolar. For example:

$\begin{array}{llll}\text { 1. /puwp/ } & \text { /puwpuw/ } & \text { poop } & \text { poohpooh } \\ \text { 2. /bab/ } & \text { /babuw/ } & \text { bob } & \text { baboo } \\ \text { 3. /kuk/ } & \text { /kukuw/ } & \text { cook } & \text { cuckoo } \\ \text { 4. /bərg/ } & \text { /bərguw/ } & \text { berg } & \text { burgoo } \\ \text { 5. /keyt/ } & \text { /keytow/ } & \text { Kate } & \text { Cato } \\ \text { 6. / suwd/ } & \text { /suwdow/ } & \text { sued } & \text { pseudo }\end{array}$

The Mandarin speaker will pronounce coke/kowk/ as/kokə/, and the Japanese speaker will pronounce cook/kuk/ as / kuku/. The Mandarin speaker will pronounce Jude/juwd/ as / judə/, and the Japanese speaker will pronounce it as / Judo/. 


\begin{tabular}{|c|c|c|}
\hline English & Mandarin & Japanese \\
\hline /kowk/ & & \\
\hline Juwd/ & / Judə/ & /Judo/ \\
\hline
\end{tabular}

The concern here, however, is not the nature of the vowel that is being added to the final stops. When the English coke /kowk/ is pronounced by the Mandarin speaker as /koka/, it sounds like coca/kowkə/. When the English cook/kuk/ is pronounced by the Japanese speaker as / kuku/, it sounds like cuckoo /kukuw/.

$\begin{array}{llll}\text { English } & & \text { Mandarin } & \text { Japanese } \\ \text { /kowk/ } & \text { coke } & \text { /kokə/ } & \\ \text { /kowkə/ } & \text { coca } & \text { /kokə/ } & \\ \text { /kuk/ } & \text { cook } & & \text { /kuku/ } \\ \text { /kukuw/ cuckoo } & & \text { /kuku/ }\end{array}$

To pronounce/kowk/ as /koka/ is as wrong as to pronounce /kuk/ as /kuku/.

When the English Jude / juwd/ is pronounced by the Mandarin speaker as /juda/, it sounds like Judah /Juwda/. When the Japanese speaker pronounces it as /Judo/, it sounds like Judo /juwdow/.

$\begin{array}{lll}\text { English } & \text { Mandarin } & \text { Japanese } \\ \text { /Juwd/ Jude } & \text { /judə/ } & \text { /judo/ } \\ \text { /Juwdə/ Judah } & \text { /judə/ } & \\ \text { /juwdow/ Judo } & & \text { /Judo/ }\end{array}$

The Mandarin substitution of / juda/ and the Japanese substitution of /judo/ for /juwd/ are both wrong. / juwd/ is neither /juda/ nor / judo/.

The crux of the matter is the difference between the occurrence of a final stop $(-C)$ and the occurrence of a stop followed by a vowel $(-\mathrm{CV})$. For in English there is such a difference.

Example 1.

$\begin{array}{lrll}\text { C } & \mathrm{CV} & & \\ \text { /kowk/ } & \text { /kowka/ } & \text { coke } & \text { coca } \\ \text { /kuk/ } & \text { /kukuw/ } & \text { cook } & \text { cuckoo }\end{array}$

In English, coke, coca, and cook, cuckoo are four different words. 
Example 2 .

$\begin{array}{ccll}\mathrm{C} & \mathrm{CV} & & \\ \text { /Juwd/ } & \text { / juwdə/ } & \text { Jude } & \text { Judah } \\ \text { /juwd/ } & \text { /Juwdow/ } & \text { Jude } & \text { Judo }\end{array}$

In English, Jude, Judah, and Judo are three different words.

Presence or absence of a vowel after a stop can make grammatical differences too. In English

1. skip dinner

2. at home

3. cook fish

4. grab few sandwiches

5. attend school

6. beg little information $\neq$ skip /a/ dinner

$f$ at $/ a /$ home

$\neq$ cook /a/ fish

$\neq$ grab $/ \partial /$ few sandwiches

$\neq$ attend / $/ \partial /$ school

$\neq$ beg $/ \partial /$ little information

The minimal difference in each pair is a vowel after a stop. Each pair is good English. Only when no vowel is called for, no vowel should occur. A speaker is obligated to make his intentions clear to his listener.

There are situations in which a vowel must not occur after a stop. When a vowel is added to a successive sequence of sounds, the result can be non-English words.

\begin{tabular}{|c|c|c|}
\hline English & \multicolumn{2}{|c|}{ non-English } \\
\hline /map/ & /mapa/ & /mapu/ \\
\hline / $\mathrm{mab} /$ & /maba/ & $/ \mathrm{mabu} /$ \\
\hline /nat/ & /nata/ & /nato/ \\
\hline /nad/ & /nade/ & /nado/ \\
\hline /nak/ & /nakə/ & /naku/ \\
\hline /nag/ & / nage/ & /nagu/ \\
\hline
\end{tabular}

When a vowel is added to a successive sequence of words, the result can be non-English constructions.

$\begin{array}{ll}\text { English } & \text { non-English } \\ \text { make a sentence } & \text { make }[\text { a] a sentence } \\ & \text { make }[\mathrm{u}] \text { a sentence } \\ \text { make sentences } & \text { make }[\partial] \text { sentences } \\ & \text { make }[\mathrm{u}] \text { sentences }\end{array}$

Both the Mandarin speaker and the Japanese speaker have the linguistic experience of producing all the stops. But neither speaker has the linguistic habit of producing all the stops in word final position. 


$\begin{array}{lll}\text { English } & {[p, t, k, b, d, g]} & {[-p,-t,-k,-b,-d,-g]} \\ \text { Mandarin } & \text { familiar } l g \text { experience } & \text { new lg habit } \\ \text { Japanese } & \text { familiar } 1 g \text { experience } & \text { new lg habit }\end{array}$

Our primary concern then is the elimination of the uncalledfor vowel after the stop, for both the Mandarin and the Japanese speakers.

Applying the principle that we so frequently hear others' obvious mistakes but are completely oblivious of our own similar ones, the teacher can ask the Mandarin speaker to hear the Japanese production, and the Japanese speaker the Mandarin production. This, however, is only a teaching device aiming at recognition. Nevertheless, once they hear the similar nature of the mistake-addition of a vowel--both the Mandarin and the Japanese speakers similarly can aim at learning to produce the unreleased allophones of all six stops. Then no vowel can occur after them.

Phonemes are realized in their allophones. Our examination of the allophonic distributions which concern us now with regard to the voiced velar stop $/ \mathrm{g} /$ in the three languages yields the following information.

\begin{tabular}{|c|c|c|c|}
\hline & & Intervocalic & Final \\
\hline English & $/ \mathrm{g} /$ & {$[\mathrm{g}]$} & {$\left[g-g^{7}\right]$} \\
\hline Mandarin & $/ g /$ & {$[\mathrm{k}]$} & \\
\hline Japanese & $/ g /$ & {$[g-\eta]$} & \\
\hline
\end{tabular}

The voiced velar stop in final position in English is realized by the Mandarin and the Japanese speakers intervocalically in the following way.

$\begin{array}{lll}\text { English } & \text { Mandarin } & \text { Japanese } \\ {[\text { nag }]} & {[\text { nagə }]} & {[\text { nagu } ~}\end{array}$

The Mandarin speaker will produce [g] but not [k]. In his native language, $[\mathrm{k}]$ and $[\mathrm{g}]$ are in predictable (complementary) distribution: $[\mathrm{g}]$ occurs before a neutral tone. The Japanese speaker will produce $[\mathrm{g}]$ or $[\mathrm{g}]$; in his native language, $[g]$ and $[y]$ are free variants $[g-y]$ in this position.

When the unreleased allophone [ $\left.\mathrm{g}^{\mathrm{T}}\right]$ of the English velar stop is taught to the Mandarin and the Japanese speakers, the Mandarin speaker will produce $\left[\mathrm{g}^{1}\right]$ and the Japanese speaker will produce $\left[g^{\urcorner} \sim \mathfrak{g}\right]$. 
In English there is a contrast between $/ \mathrm{g} /$ and $/ \mathrm{y} /$. A person speaking English is not free to vary between the two.

$$
\begin{array}{lll}
/ \text { bæg/ } / \text { bæy } / & \text { bag } & \text { bang } \\
\text { /dog/ } / \text { dəy/ } & \text { dug } & \text { dung }
\end{array}
$$

Practicing the contrast between [g] and [ $\mathrm{g}]$ is imperative for the Japanese speaker but not necessary for the Mandarin speaker. Similar to English, $/ \mathbf{y} /$ is phonemic in Mandarin Thus the lack of a similar linguistic habit $[-\mathrm{g}]$ no longer constitutes a similarity in the acquisition of this similar new habit. Phonemic distinction $/ \mathrm{g} / \neq / \mathrm{g} /$ in English and Mandarin cor-

\begin{tabular}{|c|c|c|c|c|}
\hline English & {$[\mathrm{g}] \neq=$} & {$[\mathfrak{y}]$} & $/[\mathrm{g}] / \neq /[\mathrm{g}] /$ & $\mid \mathrm{g} / \neq / \mathrm{g} /$ \\
\hline Mandarin & $\mathrm{g}] \neq$ & {$[\eta]$} & $/[\mathrm{g}] / \neq /[\mathrm{n}] /$ & $/ \mathrm{g} / \neq / \mathrm{g} /$ \\
\hline Japanese & $\sim$ & y ] & n] / & $/ \mathrm{g} /$ \\
\hline
\end{tabular}
responds to allophonic variation $/[\mathrm{g}-\mathrm{g}] /$ in Japanese.

Let us now look at the relationship between substitutions made and new linguistic habits needed.

1. Speakers of different native languages may have similar substitutions which may be considered as similar to the allophones required in the foreign language. We may then say that there is no substitution made and therefore there is no new linguistic habit needed.

$\begin{array}{lllll} & \text { English } & \text { Tagalog } & \text { Javanese } & \text { Thai } \\ / \mathrm{p} / & {\left[\mathrm{p}^{7}\right]} & {\left[\mathrm{p}^{1}\right]} & {\left[\mathrm{p}^{7}\right]} & {\left[\mathrm{p}^{1}\right]} \\ / \mathrm{t} / & {\left[\mathrm{t}^{7}\right]} & {\left[\mathrm{t}^{7}\right]} & {\left[\mathrm{t}^{7}\right]} & {\left[\mathrm{t}^{7}\right]} \\ / \mathrm{k} / & {\left[\mathrm{k}^{7}\right]} & {\left[\mathrm{k}^{1}\right]} & {\left[\mathrm{k}^{7}\right]} & {\left[\mathrm{k}^{1}\right]} \\ / \mathrm{b} / & {\left[\mathrm{b}^{7}\right]} & {\left[\mathrm{b}^{7}\right]} & & \\ / \mathrm{d} / & {\left[\mathrm{d}^{7}\right]} & {\left[\mathrm{d}^{7}\right]} & & \\ / \mathrm{g} / & {\left[\mathrm{g}^{1}\right]} & {\left[\mathrm{g}^{1}\right]} & & \end{array}$

The Tagalog speaker needs to establish no new linguistic habit in producing the English $[-p,-t,-k,-b,-d,-g]$. Neither the Javanese speaker nor the Thai speaker needs to establish any new linguistic habit in producing the English $[-p,-t,-k]$.

2. Speakers of different native languages may have similar substitutions and need to establish similar habits. 


$\begin{array}{lll}\text { English } & / b /\left[b^{7}\right] & / d /\left[d^{7}\right] \\ \text { Javanese } & / b /\left[p^{7}\right] & / d /\left[t^{7}\right] \\ \text { Thai } & / b /\left[p^{7}\right] & / d /\left[t^{7}\right]\end{array}$

Both the Javanese speaker and the Thai speaker must learn to produce the voiced stops in final position.

3. Speakers of different native languages may have similar substitutions but need different linguistic habits.

$\begin{array}{lr}\text { English } & / g /\left[\mathrm{g}^{\top}\right] \\ \text { Javanese } & / \mathrm{g} /\left[\mathrm{k}^{\top}\right] \\ \text { Thai } & {\left[\mathrm{k}^{\top}\right]}\end{array}$

The Javanese speaker must produce $[-g]$, the Thai speaker $/ g /$.

4. Speakers of different native languages may have different substitutions but need to establish a similar linguistic habit.

\begin{tabular}{lc} 
English & $/ \mathrm{p}, \mathrm{b}, \mathrm{t}, \mathrm{d}, \mathrm{k} / \rightarrow \mathrm{C}$ \\
Mandarin & $/ \mathrm{p}, \mathrm{b}, \mathrm{t}, \mathrm{d}, \mathrm{k} / \mathrm{\partial} \rightarrow \mathrm{CV}$ \\
Japanese & $/ \mathrm{p}, \mathrm{b}, \quad \mathrm{k} / \mathrm{u}>\mathrm{CV}$ \\
& \multicolumn{1}{c}{, $\mathrm{d} / \circ$}
\end{tabular}

The Mandarin and the Japanese speakers need the similar habit of eliminating the vowel after the stops. $\mathrm{CV}>\mathrm{C}$.

5. Native spakers of different languages can have different substitutions and need to acquire different habits.

$\begin{array}{ll}\text { English } & / g /\left[g^{1}\right] \\ \text { Mandarin } & / g /\left[g^{1}\right] \\ \text { Japanese } & / g /\left[g^{1}-g\right]\end{array}$

The Mandarin speaker must produce $[-\mathrm{g}]$; the Japanese speaker must separate $[-g]$ and $[-\mathrm{g}]$.

Five types of relationship of substitutions made and new linguistic habits needed have been described here. 


$\begin{array}{lll} & \text { substitution } & \text { habit } \\ \text { Type O } & \text { no } & \text { no } \\ \text { Type A } & \text { similar } & \text { similar } \\ \text { Type B } & \text { similar } & \text { different } \\ \text { Type C } & \text { different } & \text { similar } \\ \text { Type D } & \text { different } & \text { different }\end{array}$

The Tagalog speaker learning the English $/-p,-t,-k,-b,-d,-g /$ as well as the Javanese and the Thai speakers learning the English $/-p,-t,-k /$ illustrate Type $O$. The Javanese and the Thai speakers learning the English / $-b,-d /$ illustrate Type $A$. The Javanese and the Thai speakers learning the English /-g/ illustrate Type B. Mandarin and Japanese speakers learning the English / $-p,-t,-k,-b,-d /$ illustrate Type C. Mandarin and Japanese speakers learning the English $/-\mathrm{g} /$ illustrate Type D.

$\begin{array}{lcccccc}\text { English } & /-\mathrm{p} / & /-\mathrm{t} / & /-\mathrm{k} / & /-\mathrm{b} / & /-\mathrm{d} / & /-\mathrm{g} / \\ \text { Tagalog } & \mathrm{O} & \mathrm{O} & \mathrm{O} & \mathrm{O} & \mathrm{O} & \mathrm{O} \\ \text { Javanese } & \mathrm{O} & \mathrm{O} & \mathrm{O} & \mathrm{A} & \mathrm{A} & \mathrm{B} \\ \text { Thai } & \mathrm{O} & \mathrm{O} & \mathrm{O} & \mathrm{A} & \mathrm{A} & \mathrm{B} \\ \text { Mandarin } & \mathrm{C} & \mathrm{C} & \mathrm{C} & \mathrm{C} & \mathrm{C} & \mathrm{D} \\ \text { Japanese } & \mathrm{C} & \mathrm{C} & \mathrm{C} & \mathrm{C} & \mathrm{C} & \mathrm{D}\end{array}$

Substitutions made and new linguistic habits needed on the one hand, however, do not have a one-to-one correlation with linguistic experience and linguistic habit on the other.

Thus for Type $B$, the Javanese speaker has the experience $/ g /$ but not the habit $[-\mathrm{g}]$, the Thai speaker has neither the experience /g/ nor the habit [-g]. For Type D, the Mandarin and the Japanese speakers both have the experience $/ \mathrm{g} /$, and neither one has the habit [ $-\mathrm{g}]$. However, the Mandarin speaker needs to eliminate only the vowel [ $\mathrm{g}$ ə] $>[-\mathrm{g}]$, the Japanese speaker must separate the velar stop from the velar nasal in addition to eliminating the following vowel $[\mathrm{gu} \sim \mathrm{gu}]>/ \mathrm{g}[-\mathrm{g}] /$ $\neq / \eta[-n] /$.

We must then look for a different set of relationships concerning "similarities" and "differences." "Different" linguistic experience as well as "different" linguistic habits are "differences." "Similar" linguistic experiences with "different" linguistic habits are not similarities, they are "differences." "Different" linguistic habits that are "similarly" different from the same foreign language are not differences, they are "similarities." (Two linguistic habits may be different from each other, and yet they may be similarly different from the same desired 
habit.) "Similar" linguistic experiences as well as "similar" linguistic habits are "similarities." Our understanding of the problems involved in learning the six stops in English in final position by speakers of Tagalog, Javanese, Thai, Mandarin and Japanese now must be re-classified in the light of linguistic experience and linguistic habit.

Five types of relationship between linguistic experience and linguistic habit occur in the study here.

Type $O$ similar $\lg$ exp and similar lg habit (occurrence of phoneme and position)

Type 1 similar $\mathrm{lg}$ exp but diff $\mathrm{lg}$ habit (no final vd stop)

Type 2 similar $\mathrm{lg}$ exp but diff $\mathrm{lg}$ habit (no final stop)

Type 3 similar $\lg$ exp but diff $\mathrm{lg}$ habit (stop variant and no final stop)

Type 4 diff $\lg$ exp and diff $\mathrm{lg}$ habit (no occurrence of phoneme)

The Tagalog speaker learning the English / - p,-t,-k,-b,-d,-g/ as well as the Javanese and the Thai speakers learning the English / $-\mathrm{p},-\mathrm{t},-\mathrm{k} / \mathrm{illustrate}$ Type $O$. The Javanese speaker learning the English $/-\mathrm{b},-\mathrm{d},-\mathrm{g} /$ and the Thai speaker learning the English / $-b,-d /$ illustrate Type 1. The Mandarin speaker learning the English $/-\mathrm{p},-\mathrm{t},-\mathrm{k},-\mathrm{b},-\mathrm{d},-\mathrm{g} /$ and the Japanese speaker learning the English / $-\mathrm{p},-\mathrm{t},-\mathrm{k},-\mathrm{b},-\mathrm{d} / \mathrm{illustrate}$ Type 2. The Japanese speaker learning the English / $\mathrm{g} /$ illustrates Type 3 . The Thai speaker learning the English /-g/ illustrates Type 4.

$\begin{array}{lcccccc}\text { English } & /-\mathrm{p} / & /-\mathrm{t} / & /-\mathrm{k} / & /-\mathrm{b} / & /-\mathrm{d} / & /-\mathrm{g} / \\ \text { Tagalog } & \mathrm{O} & \mathrm{o} & \mathrm{O} & \mathrm{O} & \mathrm{O} & \mathrm{O} \\ \text { Javanese } & \mathrm{O} & \mathrm{O} & \mathrm{O} & 1 & 1 & 1 \\ \text { Thai } & \mathrm{O} & \mathrm{O} & \mathrm{O} & 1 & 1 & 4 \\ \text { Mandarin } & 2 & 2 & 2 & 2 & 2 & 2 \\ \text { Japanese } & 2 & 2 & 2 & 2 & 2 & 3\end{array}$

In language learning when differences among languages are differences and when similarities are found also to be differences, different exercises must be used to achieve a similar desired habit in the foreign language. When differences are found to be similarities, then the same exercises can be used to acquire a similar desired habit in the foreign language. Where there is no linguistic experience, there can be no linguistic habit. A linguistic habit is always a linguistic experience; a 
linguistic experience is not always a linguistic habit. It is only after the juxtaposed details among languages are bared that effective foreign language teaching can be achieved through concentrating on what to teach and what to drill.

\section{FOOTNOTES}

${ }^{1}$ The informants are Mrs. Emma F. Bernabe and Miss Rosalina Morales, native speakers of Manila Tagalog; Mr. Sunardjo Haditjaroko and Mrs. Moeroe'atoen Moelono, native speakers of Javanese; Mrs. Saranya Sirmpong, a native speaker of Bangkok Thai; Mrs. Hide Inada, a native speaker of Tokyo Japanese.

${ }^{2}$ Another phonemic transcription for Mandarin, preferred by many linguists, writes $/ \mathrm{p}^{\prime}, \mathrm{t}^{\prime}, \mathrm{k}^{\prime} /$ for the $/ \mathrm{p}, \mathrm{t}, \mathrm{k} /$ of this article, and $/ \mathrm{p}, \mathrm{t}, \mathrm{k} /$ for $/ \mathrm{b}, \mathrm{d}, \mathrm{g} /$ of this article, for reasons which become clear when the occurrences of allophones are tabulated in what follows.

${ }^{3}$ To assign the unreleased voiceless stops in final position to the aspirated or to the unaspirated stops is not our primary concern here. For simplicity they are assigned to the unaspirated set.

"Final aspirated voiceless stops, although "possible", are rare and stylistically very restricted in English.

5 The Japanese/b/ also has an allophone $[\beta]$ which does not occur in English.

${ }^{6}$ The Thai speaker may also produce/nag/ as [na?]. The glotral stop occurs in English but it is non-phonemic. 